\title{
Risk Rating Comparison Between Islamic Banks in Indonesia and Malaysia
}

\author{
Adelia Nidyanti ${ }^{1}$, Dodik Siswantoro ${ }^{2}$ \\ \{adelia.nidyanti81@ui.ac.id ${ }^{1}$, dodik.siswantoro@ui.ac.id² $\}$ \\ ${ }^{1,2}$ Faculty of Economic and Business, Universitas Indonesia
}

\begin{abstract}
The objective of this study is providing risk rating of Islamic banks in Indonesia and Malaysia. Islamic banks should be comply with regulations because Sharia compliance is the ultimate goal. In practice, Islamic bank customers question whether Islamic banks apply sharia principles well. However, there is no definite modeling to describe the sharia compliance. The research method of this study is descriptive quantitative which used scorecard model to score the Islamic Bank's compliance. The sample of this study is five Indonesia Islamic Bank and five Malaysia Islamic Bank. The result shows that Islamic Banks in Indonesia have satisfactory compliance rating while Islamic Banks in Malaysia mostly have high compliance rating. The contribution is providing risk rating of the Islamic Bank. The risk rating is useful to inform the customer and bank management about the compliance and risk that Islamic Bank faces.
\end{abstract}

Keywords: Risk rating, compliance, Islamic Banks

\section{Introduction}

Islamic banking has been in existence since the 1970s, and it has shown tremendous growth over the last 30 years (Hamim Ahmad Mokhtar 2008). Head to head competition with conventional banks forces Islamic banks to work harder, be more creative and more innovative to gain market share (Ascarya 2005). Islamic banking and financial system in Malaysia has a remarkable development and improvement. Malaysia began implementing dual economic systems and developed the Islamic financial and banking system since 1983 . Malaysia is first country to implement a dual banking system. Malaysia allowed conventional banking institutions to offer Islamic banking services or "Islamic windows" because it is the most effective and efficient mode to increase the number of institutions offering Islamic banking services at lowest cost and in shortest time (Hamim Ahmad Mokhtar 2008). In 1983, the first Islamic bank emerged (Bank Islam Malaysia Berhad), while the second Islamic bank established in 1999 (Bank Muamalat Malaysia Berhad). BMMB was the result of merger between Bank Bumiputra Malaysia Berhad (BBMB) and Bank of Commerce Malaysia Berhad (BOCB). The number of Islamic Bank then continue to grow. In 2006, the number of Islamic Bank in Malaysia increased to 8 . While in 2008 it increased into 12 and becoming 16 Islamic bank later in 2018. This amount is greater than Islamic Bank in Indonesia.

The Indonesian government also began to introduce a dual banking system in 1990s. The establishment of Islamic banks in Indonesia is late as compared to Malaysia in 1983. Islamic bank in Indonesia established in 1992 and since 1992, it has continued to grow according to economic conditions and various factors that influence its development (Waluyo 2016). The Financial Services Authority (OJK) continues to encourage the development of Islamic banking to grow healthy, sustainable, and contribute positively so that it can support the quality of economic development. One of the efforts made by the OJK was to issue an Islamic 
banking roadmap which began from 2015-2019. This roadmap contains a strategic plan for the development of Islamic banking in Indonesia in the form of guidance on the direction and initiative to be achieved. With this roadmap, it is expected that the development of Islamic banking industry in Indonesia can be better so that it can support financial inclusion (OJK 2016).

Based on data from the OJK, as of December 2018 there were 14 Sharia Commercial Banks in Indonesia. This number increases when compared to 2015 data where there are 12 Sharia Commercial Banks (OJK 2018). This shows the public interest in Islamic banks because Islamic banks use profit and loss sharing systems, namely the distribution of fair profits and losses between the Bank and its customers. The function of Islamic banks is basically as same as conventional banks, namely to collect and channel funds obtained from the public. However, there is one fundamental difference between conventional banks and Islamic banks, namely Islamic banks prohibit usury. Usury is the setting of interest or overestimating the number of loans when returning it. The interest usually based on a certain percentage of the principal loan amount which charged to the borrower. The purpose of prohibiting usury is to avoid wealth in only a few parties, both banks and individuals.

In carrying out its operations, the Sharia Bank is based on the Qur'an and Hadith. In addition, there are two Islamic financial institutions, namely the Islamic Financial Services Board (IFSB) and Accounting and Auditing Organization of Islamic Financial Institution (AAOIFI) whose task are preparing accounting, audit, government, and ethical standards in accordance with Islamic law for financial institutions and overseeing the Islamic Bank does not deviate from sharia principles. Islamic banks must comply with these regulations because Sharia compliance is the ultimate goal of the Islamic finance industry. Compliance with AAOIFI and IFSB standards is very important for managing sharia compliance risk, mitigating operational risk, and financial report transparency (Md. Hafij Ullah 2018).

In Indonesia, Islamic banks compliance can be seen from the compliance of sharia regulations issued by the Financial Services Authority (OJK). OJK regulate Islamic Banks to implement sharia principles, so that Islamic banks protected from interest practices (identical to usury), gambling (maysir) and uncertainty (gharar) and other practices that are not in line with sharia principles (haram). (Dedhi Ana Mey Saramawati 2014) found that the level of Islamic sharia banking compliance in Indonesia was quite adequate with a percentage exceeding to 50\%. However, (Listiana 2015) who examined the analysis of the level of compliance of Islamic banking with disclosure of sharia regulations found that the average level of disclosure of Islamic banks was around 37\%. The difference results supports (Md. Hafij Ullah 2018) that the level of sharia compliance of Islamic banks is not the same even though it is in the same regulatory and economic environment. In addition, (Ascarya 2006) states that Islamic banks in one country to another have differences because they have different environment. The factors that influence these differences are the economic system, adopted Mazhab, position of Islamic banks in law; and approach of products development.

In practice, Islamic bank customers question whether Islamic banks really apply sharia principles well. They showed their skepticism towards Islamic banks by looking at sharia compliance from Islamic banks (Muhammad Adeel Ashraf 2017) In addition, there is no definite modeling that can describe the sharia compliance of each Sharia Bank. According to (Muhammad Adeel Ashraf 2017), the level of Sharia compliance cannot be qualified as compliant or not but there must be a ranking system that regulates compliance with the law, which is high, satisfying, weak, and non-compliance.Banks with higher ratings will certainly get better ratings so they can improve their marketing. (Md. Hafij Ullah 2018) states that most 
(75\%) of respondents agree that better Shari'ah compliance will guarantee more financial benefits in Bangladesh.

Therefore, this study seeks to show the level of risk faced by Islamic banks. The study used a scorecard-based modeling approach from research conducted by (Muhammad Adeel Ashraf 2017). Ranking consists of 14 Sharia risk factors which are grouped in five main areas, namely regulations, the quality of Sharia Supervisory Board, business structure, product mixed, and the Capital Adequacy Ratio treatment. The scores obtained are then grouped into four levels that reflect the level of Shariah compliance, including non-compliance, weak, satisfactory, and high. The contribution of this paper is to provide risk rating of the Islamic Bank. The risk rating is useful to inform the customer and bank management about the compliance and risk that Islamic Bank faces. We can also compare and learn from the result between Indonesia Islamic Bank and Malaysia Islamic bank about what action should be taken to manage the risk. The sample of this study is five Indonesia Islamic bank (Bank Muamalat Syariah, Bank Syariah Mandiri, Bank Negara Indonesia Syariah, Bank Central Asia Syariah and Bank Rakyat Indonesia Syariah) and five Malaysia Islamic Bank (Bank Islam Malaysia Berhad, Amanah Malaysia Berhad, Bank Muamalat Malaysia Berhad, Maybank Islamic Berhad, and AmBank Islamic Berhad). The reason of sample selection is Indonesia and Malaysia have the same Mazhab and economic system so that the differences between two of them can be minimized. Malaysia also becoming one of world's leading centers of Islamic banking.

\section{Literature Review}

\subsection{Development of Islamic Banking in Indonesia}

The establishment of Islamic bank in Indonesia can be grouped into three phases (Mutiara Dwi Sari 2016). The first phase (Phase of Thinking) began in the 1930s. In this phase, Ulama began to think about Islamic banks and put them forward but they were not well received. The establishment of Islamic banking is still at the theoretical framework. The second phase (Preparation and Establishment Phase) began in 1980 when the Indonesian Muslim intellectuals and ulama re-visited the idea of the establishment of Islamic banks in Indonesia but their efforts still failed because of the political situation. In 1990, Indonesian Muslim Council (MUI) held a seminar to discuss the bank interest issues. The result is establish interest-free Islamic banks. The third phase (Maturation of the Concept and Setting Phase) took place from 1990 - 2000. At that time, only one Islamic bank (BMI) was established. The Islamic banking in Indonesia continue to grow slowly. The momentum for Islamic bank to grow greatly is when the government issued Islamic Banking Act No. 21 Year 2008. After that, many conventional banks spin-off their Islamic windows to full-fledged Islamic bank and conversion of rural banks to Islamic rural banks which base their operation within the Islamic tenets. This number continue to increase. In 2010, Indonesia has 10 Shariah Bank and in 2015, there are 12 Sharia Banks. According to Islamic Banking Statistics (2018), in December 2018 there were 14 Sharia Commercial Banks in Indonesia.

\subsection{Development of Islamic Banking in Malaysia}

The development of Islamic Banking in Malaysia is divided into three phase (Ascarya 2006). The first phase began on 7 April 1983 with the issuance of Islamic Banking Act (IBA). In this phase, the first Islamic bank was established (Bank Islam Malaysia Berhad). The second phase began in March 1993 by launching "Banking without Benefit Skim" or Interest 
Free Banking Scheme. In this scheme, conventional banks allowed to offer Islamic banking products. As the result, the number of bank offices offering Sharia products is increasing faster and more efficiently. In this phase, the second Islamic bank established was Bank Muamalat Malaysia Berhad. The third phase of development began with the creation of the Financial Sector Master Plan or FSMP in 2000 for the period 2000 - 2010 covering the Islamic finance sector.

\subsection{Islamic Banking Risk}

Unique risks at Islamic banks arise from the specific features Islamic contracts and the legal, governance, and liquidity infrastructure (Hesse 2008). The risk that is faced by Islamic Bank are credit risk, operational risk, liquidity risk, insolvency risk, and inherent risk. Credit risk is an important source of financial instability bank. Therefore, it is concern to measure credit risk in banking systems (Lassoued 2018). Islamic banks which use Profit Loss Sharing (PLS) increases credit risk for Islamic banks. Operational risk is also crucial. Operational risk is losses risk from inadequate or failed internal processes, people and systems or from external events, which includes legal risk and Sharīah compliance risk. The operational risk reflects the complexities associated with the administration of PLS modes, including the fact that Islamic banks often have limited legal means to control the agent-entrepreneur (Hesse 2008). Liquidity risk is probability of cash withdrawals because customers' demand exceeds bank's cash supply. Compared to conventional banks, Islamic banks incur more liquidity risk due to religious constraints on accessing interest-based funds from the money market or the central bank's lender (Md Safiullah 2018). Insolvency risk is the risk when Islamic bank runs out of capital and reserves. Inherent risk in Islamic banks happened because of the special nature of investment deposits. The capital value and rate of return are not guaranteed. According to (Lassoued 2018), as Islamic banks grow, risk management becomes more difficult so it is very important to be considered.

\section{Research method}

The method used in this study is descriptive method. The sample in this study is five Indonesia Islamic bank (Bank Muamalat Syariah, Bank Syariah Mandiri, Bank Negara Indonesia Syariah, Bank Central Asia Syariah and Bank Rakyat Indonesia Syariah) and five Malaysia Islamic Bank (Bank Islam Malaysia Berhad, Amanah Malaysia Berhad, Bank Muamalat Malaysia Berhad, Al-Amin Islamic Berhad, and AmBank Islamic Berhad). Researchers used Islamic compliance risk rating which is developed by (Muhammad Adeel Ashraf 2017). Each indicator is assessed from their 2018 annual report according to the score previously set in table 2 . A total of 14 indicators used to capture the sharia compliance level of Islamic banks. The indicators are divided into 5 categories: regulator support, quality of sharia supervision, business structure, basic composition of assets and deposits, and structure of deposits. A bank could get a maximum risk-weighted score of 150 and a minimum riskweighted score of -138 . The formula to get the percentage of each Islamic bank is 
$\%$ Shariah compliance $=\frac{\text { Achieved score } \times \text { risk weight }}{\text { maximum achievable score }}$

Table 1. Sharī ${ }^{`}$ ah risk rating model

\begin{tabular}{|c|c|c|}
\hline $\begin{array}{l}\mathbf{N} \\
\mathbf{0}\end{array}$ & Indicator & Score \\
\hline \multicolumn{3}{|c|}{ Regulatory support } \\
\hline \multirow[t]{3}{*}{1} & Legal support & \\
\hline & Separate Islamic banking law in the country & 10 \\
\hline & Single law covering Islamic and conventional banks & 6 \\
\hline \multirow{4}{*}{$\begin{array}{l}\mathbf{N} \\
\mathbf{0}\end{array}$} & Indicator & Score \\
\hline & & \\
\hline & Weak legal support for Islamic contracts & 3 \\
\hline & No legal support for Islamic contracts & 1 \\
\hline \multirow[t]{5}{*}{2} & Central Bank Support & \\
\hline & Independent supervisory board conducting Sharī'ah audit & 10 \\
\hline & Sharī'ah board with advisory function without audit & 8 \\
\hline & No Sharīah board at central bank & 3 \\
\hline & Quality of Sharī'ah supervision & \\
\hline \multirow[t]{5}{*}{3} & Independence of Sharīah supervisory function & \\
\hline & Sharī'ah advisory board reporting to BOD & 10 \\
\hline & Single Sharī'ah advisor reporting to the BOD & 6 \\
\hline & Sharī'ah advisory committee reporting to the Chief Executive Officer (CEO) & 3 \\
\hline & No Sharī‘ah committee/advisor & 0 \\
\hline \multirow[t]{5}{*}{4} & Opinion of the Sharī'ah supervisory committee/advisor & \\
\hline & Full compliance with Sharī'ah (unqualified) & 10 \\
\hline & Qualified (some exceptions) & 5 \\
\hline & Disclaimer (no opinion) & 0 \\
\hline & Adverse (Sharī'ah noncompliant) & -150 \\
\hline
\end{tabular}

5 Legal identity of Islamic banking business

Separate legal entity 10

Separately incorporated legal subsidiary of a conventional bank 8

Division with separate pool of funds of a conventional bank $\quad 7$

Branch operation of a conventional bank with mixed pools of funds 3

6 Number of Years in Sharīa ah- Compliant Business

$10+$ years $\quad 10$

3-5 years

$1-3$ years 2

Less than 1 year 1

Compliance with AAOIFI and IFSB standards compliance
Regulatory full compliance

No regulatory requirement but individual compliance $\quad 8$

Partial individual compliance $\quad 5$

No compliance $\quad 3$

8 Profit equalization reserve (PER) 


\begin{tabular}{|c|c|c|}
\hline $\begin{array}{l}\mathbf{N} \\
\mathbf{0}\end{array}$ & Indicator & Score \\
\hline & Yes & 10 \\
\hline & No & 0 \\
\hline \multirow[t]{5}{*}{9} & Charity fund & \\
\hline & Separate and independently expensed & 10 \\
\hline & Separate but not independent & 7 \\
\hline & No charity fund in place & 0 \\
\hline & Composition of asset and deposit base (Width and depth of products) & \\
\hline \multirow[t]{5}{*}{10} & Equity-based products (mushārakah, mudārabah and ijārah) & \\
\hline & More than $50 \%$ of total assets & 10 \\
\hline & 10 to $25 \%$ of total assets & 8 \\
\hline & Less than $10 \%$ of total assets & 5 \\
\hline & No mushārakah/mudārabah based assets & 0 \\
\hline \multirow[t]{5}{*}{11} & Width of asset Products & \\
\hline & 10 or more financing products & 10 \\
\hline & 5 to 10 financing products & 8 \\
\hline & 2 to 5 financing products & 5 \\
\hline & 1 to 2 financing products & 2 \\
\hline \multirow{5}{*}{12} & Debt-based products (murābahah and tawarruq as \% of total financing) & \\
\hline & Less than $10 \%$ & 10 \\
\hline & 10 to $33 \%$ & 6 \\
\hline & 33 to $66 \%$ & 4 \\
\hline & Above $66 \%$ & 2 \\
\hline \multirow[t]{4}{*}{13} & Structure of deposit & \\
\hline & Separate deposit pools under mudārabah/mushārakah partnership & 10 \\
\hline & Murābahah-based deposit & 6 \\
\hline & Current/saving deposit contracts under qard & 5 \\
\hline \multirow[t]{6}{*}{14} & Capitaladequacystandards(asperIFSB) & \\
\hline & $\begin{array}{l}\text { IFSB CAR (capital/risk weighted assets (RWA) -RWA (profit sharing investment } \\
\text { accounts (PSIA)) }\end{array}$ & \\
\hline & $2 \%$ above the applicable Basel CAR (Basel II/III) & 10 \\
\hline & Equal to Basel CAR & 1 \\
\hline & Less than Basel CAR & -10 \\
\hline & Not available & 1 \\
\hline
\end{tabular}

Source : Ashraf dan Lahsasna (2017)

After we obtain the percentage value of Sharia Bank compliance, then Bank is classified according to table 3 .

Table 2. Rating table

\begin{tabular}{ccc}
\hline Achieved degree of compliance & Rating & Interpretation \\
\hline$\geq 80 \%$ & SSS & high shariah compliance \\
$50 \%-80 \%$ & S+ & Satisfactory shariah compliance \\
$0-50 \%$ & S- & Weak shariah compliance \\
Negative score & SN & shariah non compliance \\
\hline
\end{tabular}

Source : Ashraf dan Lahsasna (2017) 


\section{Result and discussion}

The scoring result of Islamic Banks in Indonesia and Malaysia can be seen in table 4.

Table 3. The level of shariah compliance

\begin{tabular}{|c|c|c|c|}
\hline Bank name & $\begin{array}{l}\text { Achieved degree of } \\
\text { shariah compliance }\end{array}$ & Percentage & Rating \\
\hline \multicolumn{4}{|c|}{ Indonesia } \\
\hline Muamalat & $111 / 150$ & $74.00 \%$ & S+ (Satisfactory shariah compliance) \\
\hline BSM & $104 / 150$ & $69.33 \%$ & S+ (Satisfactory shariah compliance) \\
\hline BCAS & $111 / 150$ & $74.00 \%$ & S+ (Satisfactory shariah compliance) \\
\hline BNIS & $113 / 150$ & $75.33 \%$ & S+ (Satisfactory shariah compliance) \\
\hline BRIS & $119 / 150$ & $79.33 \%$ & S+ (Satisfactory shariah compliance) \\
\hline \multicolumn{4}{|c|}{ Malaysia } \\
\hline BIMB & $121 / 150$ & $80.67 \%$ & SSS (high shariah compliance) \\
\hline Amanah & $124 / 150$ & $82.67 \%$ & SSS (high shariah compliance) \\
\hline Muamalat & $117 / 150$ & $78.00 \%$ & S+ (satisfactory shariah compliance) \\
\hline AmBank & $118 / 150$ & $78.67 \%$ & S+ (satisfactory shariah compliance) \\
\hline Al-Amin & $128 / 150$ & $85.33 \%$ & SSS (high shariah compliance) \\
\hline
\end{tabular}

From table 4, we can see that all of Indonesia Islamic bank in this study have satisfactory shariah compliance rating. The percentage of shariah compliance ranging from $69,33 \%$ to $79,33 \%$. Bank Rakyat Indonesia syariah has the highest percentage of shariah compliance $(79,33 \%)$, while Bank Muamalat Indonesia has $74 \%$. It means that the number of years bank established does not affected the shariah compliance in Indonesia. The lowest percentage of shariah compliance is Bank Syariah Mandiri. On the other hand, most of Islamic bank in Malaysia have high shariah compliance rating, such as BIMB, Amanah Malaysia Berhad, and Al-Amin Islamic Berhad.The percentage of shariah compliance ranging from $80,67 \%$ to 85,33\%. While Bank Muamalat Malaysia and AmBank Islamic Berhad have satisfactory shariah compliance rating.

Indonesia and Malaysia have separate Islamic Banking law in their country, but the regulation in Malaysia more comprehensive compare with regulation in Indonesia. Shariah supervisory board in Malaysia has different task with Indonesia. In Malaysia, shariah supervisory board has authority to conduct shariah audit of Islamic Financial Institutions while shariah supervisory board in Indonesia does not have those authority. In Indonesia shariah supervisory board only give advisory to Islamic Bank. Beside that, In Indonesia there is a single shariah supervisory board (Dewan Pengawas Syariah) which is reporting to the Board of Director. While in Malaysia, the shariah supervisory board reporting to Board of Director.

Business structure of Islamic Bank in Indonesia and Malaysia is also different. Most of Islamic Bank in Malaysia have separate legal entity. While majority Islamic Bank in Indonesia is legal subsidiary of a conventional bank. The number of years of the Islamic bank established in Malaysia are more than 10 years. Bank Islamic Malaysia Berhad established for 35 years. While the number of years of Islamic Bank established in Indonesia ranging from 8 to 27 years. The regulation in Indonesia and Malaysia refers to AAOIFI standards so almost all of the sample are comply with shariah principles. In Indonesia, the Profit Equalization Reserve for Islamic Bank has not fully conducted, while Islamic Bank in Malaysia have Profit Equalization Reserve.

Equity based products in Indonesia such as musharakah, mudarabah and ijarah is ranging from 10 to $25 \%$ of total assets, while equity products in Malaysia has variation amount from 
10 to more than $50 \%$ of total assets. Debt based product in Indonesia and Malaysia are ranging from 33 to $66 \%$. The structure of deposit in Indonesia is dominated by mudharabah and musharakah. On the other hand, the structure of deposit in Malaysia is dominated by Murabahah. Islamic Bank in Indonesia and Malaysia also comply with Capital Adequacy Ratio standard which regulate by IFSB. Each of Islamic Bank in the sample have CAR above the standard which means that the Islamic Bank have enough amount of capital to cover the risk so the Islamic Bank will not bankrupt.

\section{Conclusion}

The development of Islamic Bank in Indonesia and Malaysia is enormously. The number of Islamic Bank has continously grown. It means that customers are interested by Islamic Banking products. Islamic banks must comply with regulations because Sharia compliance is the ultimate goal. On the other hand, Islamic bank customers question whether Islamic banks really apply sharia principles well. According to (Muhammad Adeel Ashraf 2017), the level of Sharia compliance cannot be qualified as compliant or not but there must be a ranking system that regulates compliance with the law (high, satisfying, weak, and non-compliance). In addition, there is no definite modeling that can describe the sharia compliance of each Islamic Bank. This study trying to show the level of risk faced by Islamic banks. The study used a scorecard model from (Muhammad Adeel Ashraf 2017).

This study find that all of Indonesia Islamic bank in this study have satisfactory shariah compliance rating. The percentage of shariah compliance ranging from $69,33 \%$ to $79,33 \%$. On the other hand, most of Islamic bank in Malaysia have high shariah compliance rating (BIMB, Amanah Malaysia Berhad, and Al-Amin Islamic Berhad).The percentage of shariah compliance ranging from $80,67 \%$ to $85,33 \%$. While Bank Muamalat Malaysia and AmBank Islamic Berhad have satisfactory shariah compliance rating. From the result we can conclude that Islamic Bank in Malaysia more comply with shariah principles than Islamic Bank in Indonesia. It is probably because Islamic Bank in Malaysia have already establised earlier than Islamic Bank in Indonesia so they have already more understand about the risk they faced. Beside that, regulation in Malaysia is more comprehensive than in Indonesia. It can be seen that Malaysia has a set of regulations governing shariah audit. Shariah audit can help Islamic Bank to comply with shariah principle. The contribution of this paper is to provide risk rating of the Islamic Bank to inform the customer and bank management about the compliance and risk that Islamic Bank faces. The limitation of this study is only use two country as comparison. Future rearch can consider another country that have Islamic Bank.

\section{References}

[1] Ascarya (2006). Comparing Islamic Banking Development in MALAYSIA and INDONESIA: Lessons for Instruments Development. Directorate of Monetary Management Bank Indonesia. Jakarta, Indonesia, Center for Central Banking Education and Studies

[2] Ascarya, D. Y. (2005). Bank Syariah: Gambaran Umum. Jakarta, Center for Central Banking Education and Studies.

[3] Dedhi Ana Mey Saramawati, A. T. L. (2014). "Analisis Pengungkapan Sharia Compliance dalam Pelaksanaan Good Corporate Governance Bank Syariah Indonesia." Jurnal Akuntansi dan Keuangan Islam 2(2): 107-126. 
[4] Hamim Ahmad Mokhtar, N. A., Syed M. Al-Habshi (2008). "Efficiency and competition of Islamic banking in Malaysia." Humanomics 24(1): 28-48.

[5] Hesse, M. Č. a. H. (2008). "Islamic Banks and Financial Stability: An Empirical Analysis." IMF Working Paper.

[6] Lassoued, M. (2018). "Comparative study on credit risk in Islamic banking institutions: The case of Malaysia." The Quarterly Review of Economics and Finance 70: 267-278.

[7] Listiana, L. (2015). Analisis Tingkat Kepatuhan Perbankan Syariah terhadap Pengungkapan menurut Ketentuan Syariah. Economic and business. Depok, Universitas Indonesia. Master.

[8] Md Safiullah, A. S. (2018). "Risk in Islamic banking and corporate governance." Pacific-Basin Finance Journal 47: 129-149.

[9] Md. Hafij Ullah, R. K. (2018). "Whether Shari ah compliance efficiency a matter for the financial performance: the case of Islami Bank Bangladesh Limited." Journal of Islamic Accounting and Business Research 9(2): 183-200.

[10] Md. Hafij Ullah, R. K., Tabassum Tasnim (2018). "Comparative compliance status of AAOIFI and IFSB standards: an empirical evidence from Islami Bank Bangladesh Limited." Journal of Islamic Accounting and Business Research 9(4): 607-628.

[11] Muhammad Adeel Ashraf, A. L. (2017). "Proposal for a new Shariah risk rating approach for Islamic Bank." ISRA International Journal of Islamic Finance 9(1).

[11] Mutiara Dwi Sari, Z. B., Zahra Hamat (2016). "History of Islamic bank in Indonesia: Issues behind its establishment." International Journal of finance and banking research 2: $178-184$.

[12] OJK (2016). "Roadmap Keuangan Berkelanjutan." 2019, from https://www.ojk.go.id/sustainable-finance/id/publikasi/panduan/Pages/RoadmapKeuangan-Berkelanjutan.aspx.

[13] OJK (2018). "Sharia Banking Statistics." 2019, from https://ojk.go.id/en/kanal/perbankan/data-dan-statistik/statistik-perbankansyariah/Default.aspx.

[14] Waluyo, A. (2016). "KEPATUHAN BANK SYARIAH TERHADAP FATWA DEWAN SYARIAH NASIONAL PASCA TRANSFORMASI KE DALAM HUKUM POSITIF." Jurnal Penelitian Sosial Keagamaan 10(2). 